\title{
NORTH ATLANTIC CIVIL AVIATION: LIBERALIZATION VS. CRISIS - A REGRESSION ANALYSIS
}

\section{Martin Grančaya}

${ }^{a}$ Vice-Dean for Development, Assistant Professor, Ph. D, University of Economics in Bratislava, Faculty of International Relations, Department of International Economic Relations and Economic Diplomacy, Bratislava, Slovakia, martin.grancay@ euba.sk.

\section{ARTICLE INFO}

Article data:

- Received: 15 February 2012

- Accepted: 26 September 2012

JEL classification: L93

Keywords:

- air transportation

- economic crisis

- North-Atlantic market

- open skies

\section{ABSTRACT}

In 2007, the European Commission and US government signed an agreement liberalizing international air transportation between the two continents. It was expected to increase the annual number of passengers by up to 11 million and generate more than 5 billion EUR in consumer surplus. However, in 2008 the market was struck by global economic crisis. We use regression analysis to distinguish between positive impacts of liberalization and negative impacts of the crisis. We come to the conclusion that had the market not been reinforced by liberalization, annual transatlantic traffic would have shrunk at a pace 3-7 million passengers faster. The results are a clear indication that if European and US airlines want to remain competitive in the coming era of Asian dominance, further liberalization efforts have to be undertaken.

Reference to this paper should be made as follows: Grančay. M. 2013. North Atlantic civil aviation: liberalization vs. crisis - a regression analysis, Ekonomska istraživanja - Economic Research 26(4): 101-112 


\section{INTRODUCTION}

While international trade with the majority of commercial services was liberalized in 1995 when General Agreement on Trade in Services (GATS) entered into force, air transportation has remained one of the most protectionist sectors of any country's economy (Lipková, 2011). Almost 70 years after the adoption of the Convention on International Civil Aviation in Chicago (1944) civil aviation relations between countries are still governed by this old document. Establishing direct flights from a point $A$ in country $X$ to a point $B$ in country $Y$ requires bilateral agreement between the countries. The agreement determines the number of flights permitted per week, sets frequency, capacity, aircraft type and price restrictions. Until recently, the US-EU aviation relations used to be no exception.

The successful creation of common aviation market of the European Union in 1997 directed the attention of the European Commission to international markets where USA was following its "divide and conquer strategy" (Zhang and Zhang, 2002) of signing separate bilateral agreements with EU member states. These discriminated airlines on the basis of their nationality and hence were in direct contradiction with the Treaty of Rome. A separate bilateral agreement between USA and France meant that only French and US-owned airlines were allowed to operate scheduled direct air services between USA and France. Analogically, a separate bilateral agreement between USA and Belgium meant that only Belgian and US-owned airlines were allowed to operate scheduled direct air services between USA and Belgium. As a result of this, the European Court of Justice decided in November 2002 that by entering into separate relations with USA EU member states violated Community law. The European Commission therefore launched a campaign to negotiate a common agreement with USA.

After four years of negotiations the US-EU Open Skies Agreement was signed in 2007 and entered into force on March 30th 2008. The agreement significantly liberalizes the North Atlantic market and includes the following most important measures: (Hasan, 2008)

- all US and EU-based airlines are allowed to operate flights between any point in the EU and any point in USA;

- USA accepts the Community air carrier concept i.e. airlines owned by nationals of any EU member state have the same rights and obligations;

- no capacity or frequency limits on North-Atlantic flights;

- free pricing;

- unlimited code-sharing for both sides;

- alliances between US and EU airlines qualify for antitrust immunity.

The goal of this paper is to analyze impacts of the US-EU Open Skies Agreement on transatlantic passenger flows and compare them to scientific predictions. We use simple linear regression models to distinguish between the positive impacts of liberalization and negative impacts of the global economic crisis 2008-2009.

\section{THE US-EU OPEN SKIES AGREEMENT - GREAT EXPECTATIONS}

Before adopting the US-EU Open Skies Agreement both parties had performed a series of analyses of its potential impacts. Major studies dealing with the topic include the Brattle report (Brattle Group, 2002), the Booz-Allen-Hamilton report (Bhadra and Schaufele, 2007), a paper by Robyn et 
al (2005), Mayor and Tol (2007), Alford and Champley (2007), Peterson and Graham (2007) and a few others.

The first study analyzing potential impacts of the Agreement was the Brattle report, prepared on behalf of the European Commission in 2002. It predicted the Agreement would lead to an annual increase in the number of transatlantic passengers by 4-11 million and to a total increase in the number of intra-EU passengers by 13-36 million over a period of five years. Moreover, lower operating costs of airlines would lead to lower prices, increased travel and an annual consumer surplus of 5.2 billion EUR. On the supply side, annual economic output of directly related industries was expected to grow by 3.6 to 8.1 billion EUR. Also, a creation of 4,800 to 16,300 jobs was predicted, evenly distributed between the EU and USA.

In 2007 the European Commission commissioned Booz Allen Hamilton consulting company to compile a new report. Using the same methodology as the Brattle report and adjusting it to new conditions in the world economy, it intended to predict impacts of the Open Skies Agreement for a period of 5 years after its adoption. It approximated the increase in transatlantic travel to 26 million, i.e. 50 per cent compared to the base year. Other predictions included consumer surplus ranging from 6.4 to 12.0 billion EUR, creation of 20,000 new direct jobs and further 50,000 more indirect jobs. In general, the Booz-Allen-Hamilton report's predictions were considerably more optimistic compared to the Brattle report. This could be attributed to the boom in air travel that superseded previous pessimism fueled by dot.com crisis and 9-11 attacks. Furthermore, while the Brattle report was based on the 15-member EU, the Booz-Allen-Hamilton model already took into account the enlarged EU counting 25 member states. Aviation markets of the newcomers were less developed and hence their growth potential was higher.

TABLE 1. ESTIMATES OF THE US-EU OPEN SKIES AGREEMENT IMPACTS

\begin{tabular}{llll}
\hline & Brattle lower & Booz Allen Hamilton & Robyn et al \\
\hline \hline $\begin{array}{l}\text { Annual transatlantic pas- } \\
\text { senger growth }\end{array}$ & 4.1 million & 5.2 million & 11.0 million \\
$\begin{array}{l}\text { Annual EU passenger } \\
\text { growth }\end{array}$ & 13.6 million & - & 35.7 million \\
$\begin{array}{l}\text { Annual economic output } \\
\text { growth }\end{array}$ & 3.6 billion & - & 8.1 billion \\
Consumer surplus & 5.1 billion & $1.3-2.4$ billion & 5.2 billion \\
New jobs & 4,800 & 22,000 & 16,300 \\
\hline \hline
\end{tabular}

Source: Brattle Group (2002), Robyn et al (2005), Bhadra and Schaufele (2007)

Other significant studies analyzing potential impacts of the Open Skies Agreement include Dorothy Robyn's article published in 2005 (Robyn et al, 2005). Robyn was a member of the original Brattle report group and she further elaborated the upper-case scenario. She believed the improving state of the global economy and EU enlargement allowed for higher-than-previously-expected predictions. Moreover, one of the crucial Brattle report assumptions was a stable 1 USD to 1 EUR exchange rate, which - at the time of Robyn's study - was far from reality. Estimates of the three most commonly cited reports are shown in table 1 . 
On the other side of the debate, Mayor and Tol (2008) argued previous studies were too optimistic and a more realistic estimate of total passenger growth would be somewhere between 1 and 14 per cent, depending on the magnitude of price reductions.

\section{METHODOLOGY AND DATA}

The majority of studies applying linear regression models to analyze changes in air traffic use annual GDP growth rate as a single predictor variable. The practice is related to air transportation being a luxurious good with direct elasticity of demand ranging from 1.5 to 2.5 (see for example Intervistas, 2007 and Doganis, 2006). After having performed more than twenty regression analyses with various predictor variables (such as volume of exports, imports, foreign direct investment, USD/EUR exchange rate etc.) we come to the conclusion that apart from annual GDP growth rate another suitable predictor variable for analyzing North Atlantic air traffic is average annual unemployment rate. Consequently, we use the following four models:

$$
\begin{aligned}
& \Delta P a x=a+b_{1} \Delta G D P \_U S+b_{2} \Delta G D P \_E U+b_{3} U \_U S+b_{4} U \_E U+e \\
& \Delta P a x=a+b_{1} \Delta G D P \_U S+b_{3} U \_U S+b_{4} U \_E U+e \\
& \Delta \mathrm{Pax}=a+b_{1} \Delta \mathrm{GDP} \_\mathrm{US}+e \\
& P a x=a+b_{3} U \_U S+e \\
& \triangle P a x=\text { annual growth of traffic } \\
& \text { Pax = annual number of passengers } \\
& \triangle G D P \_U S=\text { annual GDP growth rate in USA } \\
& \triangle G D P \_E U=\text { annual GDP growth rate in the EU } \\
& \text { U_US = average annual unemployment rate in USA } \\
& \text { U_EU = average annual unemployment rate in EU } \\
& \text { e } \quad=\text { random variable } \\
& \text { a = intercept } \\
& b_{1}-b_{4} \quad=\text { regression parameters }
\end{aligned}
$$

The main goal of our research was to explain the largest possible fraction of variance in the number of North Atlantic passengers with the help of the fewest possible predictor variables. Therefore, the models we use are relatively simple. Using annual GDP growth rate instead of GDP per capita we minimize the risk of heteroskedasticity. However, similar approach is not suitable for unemployment data, where a risk of heteroskedasticity exists. 
Regression models 1, 2 and 3 are based on 2000-2007 data. US-EU aviation relations in this period were governed by a wide array of bilateral agreements, most of them of a relatively protectionist nature. The dataset accounts for impacts of the dot.com crisis and terrorist attacks of 9-11. Regression model 4 is based on the data from crisis years 2000-2002. Except for model 4 which uses monthly data, all other models are based on average annual data.

The sources of data we used for regression analysis include Eurostat and US Department of Transportation Statistics. Annual GDP growth rates and unemployment rates are based on Eurostat data. Annual unemployment rate data were calculated by author from Eurostat monthly average unemployment rate data using a simple geometric average. Transatlantic traffic data was extracted from the US Bureau of Transportation Statistics T-100 International Segment (all carriers) database, which is published with a 6-month delay. We processed this data using 12-month simple moving average method to adjust for seasonal variation.

TABLE 2. DATA SOURCES FOR REGRESSION ANALYSIS

\begin{tabular}{|c|c|}
\hline & Data source \\
\hline GDP growth rate & EUROSTAT: Real GDP growth rate. Available at: http://epp.eurostat.ec.europa.eu. \\
\hline Unemployment rate & $\begin{array}{l}\text { EUROSTAT: Unemployment rate, monthly average, by sex and age groups. Avail- } \\
\text { able at: http://epp.eurostat.ec.europa.eu. }\end{array}$ \\
\hline Number of passengers & $\begin{array}{l}\text { US DOT Bureau of Transportation Statistics: T-100 International segment (all carri- } \\
\text { ers). Available at: http://www.transtats.bts.gov. }\end{array}$ \\
\hline
\end{tabular}

Source: Own elaboration

After testing the quality of models, we applied them to 2008-2011 data in order to determine positive effects of the US-EU Open Skies Agreement and separate them from negative impacts of the global economic crisis.

\section{REGRESSION ANALYSIS AND FINDINGS}

All the models used have high correlation coefficients and coefficients of determination, indicating good fits. The predictor variables explain a high proportion of variance in the number of North Atlantic passengers. $F$ statistics of all the models is also statistically highly significant which further implies high degree of goodness of fit (table 3 ).

Model 1 has the highest coefficient of determination. However, although it is statistically highly significant, the problem lies in the P-value of intercept and parameters, only one of them ( $\triangle$ GDP_US) being statistically significant. That indicates unsuitability of the model to predict number of passengers. An interesting feature of this model is the positive value of parameter $U_{-}$ US. This means higher unemployment rate in USA should lead to increased number of North Atlantic passengers, which contravenes economic logic.

With the exception of intercept all the parameters of model 2 are statistically significant. The model only differs from model 1 in that it does not include EU GDP growth rate. It can there- 
fore be claimed that while the number of North Atlantic passengers depends directly on the GDP growth rate in USA, the GDP growth rate in the EU plays no statistically significant role. This claim was independently confirmed by the Booz-Allen-Hamilton report, using a different approach and different dataset, but effectively coming to the same conclusion (Bhadra and Schaufele, 2007).

TABLE 3. REGRESSION STATISTICS AND PARAMETERS

\begin{tabular}{|c|c|c|c|c|}
\hline & Model 1 & Model 2 & Model 3 & Model 4 \\
\hline Multiple R & 0.989426 & 0.989287 & 0.904694 & 0.959463 \\
\hline R Square & 0.978963 & 0.978689 & 0.818472 & 0.920569 \\
\hline $\begin{array}{l}\text { Adjusted } \\
\text { R Square }\end{array}$ & 0.950914 & 0.962706 & 0.788217 & 0.918233 \\
\hline Standard Error & 1.602639 & 1.396920 & 3.328894 & $44,237.35$ \\
\hline Significance F & 0.007532 & 0.000845 & 0.002012 & 0.000001 \\
\hline $\begin{array}{l}\text { Intercept } \\
\text { (P-Value) }\end{array}$ & $\begin{array}{l}11.694680 \\
(0.698139)\end{array}$ & $16.85005(0.079910)$ & $-15.3054(0.004697)$ & $2,714,161(0.000001)$ \\
\hline $\begin{array}{l}\triangle \text { GDP_US } \\
\text { (P-Value) }\end{array}$ & $8.286673(0.013335)$ & $8.559547(0.000199)$ & $6.591456(0.002012)$ & - \\
\hline $\begin{array}{l}\triangle G D P \text { GU } \\
\text { (P-Value) }\end{array}$ & $0.547813(0.856056)$ & - & - & - \\
\hline $\begin{array}{l}\text { U_US } \\
\text { (P-Value) }\end{array}$ & $3.962990(0.212333)$ & $3.527063(0.027482)$ & - & $-182,249(0.000001)$ \\
\hline $\begin{array}{l}\text { U_EU } \\
\text { (P-Value) }\end{array}$ & $-6.158470(0.050438)$ & $-6.434600(0.005411)$ & - & - \\
\hline
\end{tabular}

Source: Own calculations

Model 2 has the same peculiarity as model 1, suggesting high unemployment rate in USA leads to high number of passengers; however, unlike with model 1, both parameters are now statistically significant. This counterintuitive claim can only be explained with possible partial collinearity between unemployment rate and GDP growth rate in USA. 
Models 3 and 4 are very simple, each of them taking into account only one predictor variable. Both are statistically highly significant and their intercepts and parameters are statistically significant as well.

Model 3 shows a high level of correlation between GDP growth rate in USA and the number of passengers. This finding is reinforced by general knowledge of economic theory - air transport is a luxury good and as such it is consumed proportionally to the rising level of income. If the growth rate falls below certain level (in this case 2.3 per cent) the consumption of goods starts to decrease. According to model 3 , in case of stagnant US economy the number of passengers on the North Atlantic market will shrink by 5 per cent. This result is in line with the latest research in air travel demand elasticity (see Intervistas, 2007 and Doganis, 2006).

While models 1-3 are based on annual data 2001-2007, model 4 is based on monthly US unemployment data from crisis years 2000-2002. The model and its parameters are statistically highly significant. Negative value of the U_US parameter meets our expectations of passenger growth being negatively correlated to unemployment rate.

Regression analysis results in these equations:

$$
\begin{aligned}
& \Delta P a x=1.695+8.287 \Delta G D P \_U S+0.548 \Delta G D P \_E U+3.963 U \_U S+6.158 U \_E U+e \\
& \Delta P a x=16.850+8.560 \Delta G D P \_U S+3.527 U \_U S+6.435 U \_E U+e \\
& \Delta P a x=-15.305+6.591 \Delta G D P \_U S+e \\
& P a x=2,714,161+182,249 U_{-} U S+e
\end{aligned}
$$

Applying equations 5-8 to data from years 2008-2011 and comparing model values with real North Atlantic passenger data (table 4) we get an insight of how well models 1-4 perform. 
TABLE 4. NORTH ATLANTIC PASSENGER TRAFFIC 2005-2010 - REALITY VS. MODELS

\begin{tabular}{|c|c|c|c|c|}
\hline & Model 1 & Model 2 & Model 3 & Model 4 \\
\hline 2005 & $23,656,386$ & $23,027,691$ & $23,383,873$ & $23,775,926$ \\
\hline 2006 & $24,283,654$ & $23,988,803$ & $24,319,112$ & $24,245,795$ \\
\hline 2007 & $25,187,187$ & $23,211,891$ & $25,019,187$ & $23,608,174$ \\
\hline 2008 & $25,151,600$ & $19,548,792$ & $22,397,694$ & $20,834,129$ \\
\hline 2009 & $23,338,509$ & $13,093,346$ & $16,350,886$ & $16,162,694$ \\
\hline 2010 & $23,326,404$ & $22,741,788$ & $25,071,707$ & $23,458,493$ \\
\hline 2011 & $24,222,303$ & $22,290,503$ & $23,655,038$ & $22,523,796$ \\
\hline
\end{tabular}

Source: Own calculations

It is obvious that the real number of North Atlantic passengers in years 2008 and 2009 was much higher than our models would have expected. The difference between predicted and real values for the crisis years reached 11-22 per cent in 2008 and 30-47 per cent in 2009. In 2010, when the GDP growth in USA as well as in the EU rebounded, the difference decreased to 3-7 per cent and in 2011 to 2-8 per cent (both with the exception of model 4).

The worst performer from among models used is model 4 - its predictions of 12 million passengers in 2009 and 13 million in 2011 are significantly underestimated. As a result, unemployment rate in USA does not seem to be a good predictor variable for number of passengers and therefore we will omit this model from further analysis.

We have already shown that model 1 as a whole is statistically highly significant, but its parameters are not. Conversely, regression statistics values of models 2 and 3 are acceptable and the models seem to have a high degree of goodness of fit. Therefore, after a thorough analysis of the regression statistics and model parameters we come to the conclusion that the best predictions are offered by models 2 and 3 . According to these models the number of passengers on the North Atlantic market in 2009 should have been approximately 7 million lower than it really was. Assuming our models are correct, these 7 million passengers can be interpreted as direct impact of the US-EU Open Skies Agreement.

The difference between modeled and actual number of passengers is similar to the impact predicted by middle scenario of the Booz-Allen-Hamilton report. This leads us to believe our models are suitable and their performance when adjusted for impacts of the global economic crisis are correct. Additional factor supporting our hypothesis is the North Atlantic traffic in 2010. 2010 was a year of renewed growth in USA as well as in the European Union, with GDP rising 2.4 and 2.1 per cent. This was in line with average GDP growth in the first years of the 21st century. However, the world did not exit the crisis yet and neither did civil aviation. Actual number of North Atlantic passengers in 2010 fell to 23 million, a net loss of 2 million passengers compared to 2007. Applying 
models 2 and 3 to 2010 data we can see they provide a very good fit. This means positive effects of liberalization were approximately equal to negative impacts of the subsiding global economic crisis, a very believable scenario supported by IATA year-end traffic data.

\section{DISCUSSION}

Our approach is not free of problems. First, a typical problem of linear regression models is their inability to identify all predictor variables that influence the response variable. This is especially the case in today's globalized world characterized by increasing velocity of internationalization processes, where it is almost impossible to meet the ceteris paribus assumption. Second, even though we used a 12-month moving average method to minimize distortions caused by shortterm external shocks, regression analysis is not really able to recognize and reflect new conditions in the world economy. We can claim with utmost certainty that the global economic crisis 20082009 changed the conditions on the North Atlantic aviation market and hence decreased the suitability of regression models based on pre-crisis data. Unfortunately, quantifying the magnitude of this change is at present time impossible. However, judging from statements of top-level managers of large international airlines, it is clear the crisis has led to a permanent rise of income elasticity of demand for business class travel, shift of a part of business passengers to economy class as well as increase of the overall importance of air tariffs for passengers' decision-making. Moreover, it seems obvious that the second wave of crisis is coming and has already started affecting the North-Atlantic market.

We believe it is reasonable to claim that the US-EU Open Skies Agreement has had a significant positive impact on the number of North-Atlantic passengers. However, as the models used admittedly have some minor flaws, we think the result obtained, i.e. 7 million passengers, is overestimated. A much more realistic estimate seems to be 3 million, as predicted by Booz-Allen-Hamilton's lower scenario. The difference could be explained by changed economic conditions and general decrease of air tariffs triggered by the crisis.

From Croatian point of view, the US-EU Open Skies Agreement set a framework allowing all American and European airlines to operate direct flights between any American and European airports. While there is currently no such service from Croatia, some new EU-member states (Czech Republic, Hungary, Poland, Latvia etc.) have direct flights to USA. In the future the Agreement could play a vital role in launching direct flights between USA and Croatia, especially taking into account new aircraft models specifically designed for thin routes (Boeing 787 Dreamliner and Airbus A350) and potential entry of low-cost carriers into the North Atlantic market.

\section{CONCLUSION}

The US-EU Open Skies Agreement's entry into force in 2008 was attended by expectations of significant rise in the number of North-Atlantic passengers. Annual contribution of liberalization was expected to reach 4-11 million passengers and even the most conservative forecasts approximated the size of the market in 2009 to no less than 30 million. The global economic crisis 20082009 made all the predictions useless sheets of paper - compared to 2007 the 2009 volume of the market shrank by 1.8 million passengers or 7.9 per cent, reaching only 23.34 million. In 2010 it decreased even further to 23.32 million.

On the basis of our regression analysis we come to the conclusion that despite crisis-related negative trend in the number of passengers, importance of the US-EU Open Skies Agreement is undisputable. Had the North Atlantic market still been divided into separate bilateral US-EU 
country markets, the 2009 volume of traffic would have been lower by 7 million passengers. This number might be overestimated due to lower air tariffs and unidentified long-term structural changes to the market caused by the global crisis. A more conservative estimate of impacts of the Agreement is 3 million passengers in 2009. These results are in accord with one of the most-widely cited pessimistic scenario of impacts of the Agreement prepared by Booz-Allen-Hamilton (see Bhadra and Schaufele, 2007).

The Agreement and its economic impacts, having passed only four years from its adoption, will be a very important topic of research in the coming years. It will be interesting to observe its performance after the crisis is finally over and compare it with the pre-crisis forecasts. Obviously the most challenging task will be to identify and quantify impacts of qualitative changes triggered by the crisis. The results of such research will be crucial for long-term profitability of airlines and might finally settle the seemingly never-ending academic debate between supporters of protectionism and liberalism in air transportation. For now, it seems European and US airlines can successfully compete with their Asian and Middle-Eastern counterparts only if European and US governments increase their liberalization efforts. Then, if North-Atlantic air transport liberalization becomes a story of success, liberalization in other corners of the world will surely follow suit. 


\section{ACKNOWLEDGEMENTS}

I would like to thank two anonymous referees for valuable comments on previous version of this paper. The paper was supported by a grant VEGA 1/0911/11 "Štyri slobody pohybu v Európskej únii" coordinated by prof. Lipková.

\section{REFERENCES}

Alford, E. and Champley, R. The Impact of the 2007 U.S.-EU Open Skies Air Transport Agreement, ITA, Washington, 2007.

Bhadra, D. and Schaufele, R. Impacts of US-EU Open Aviation Area Treaty on US and the EU, BoozAllen-Hamilton, London, 2007.

Brattle Group. The Economic Impact of an EU-US Open Aviation Area, The Brattle Group, London, 2002.

Doganis, R. The Airline Business, Routledge, Abingdon, 2006.

Grančay, M. “Liberalizácia severoatlantickej leteckej dopravy a hospodárska kríza - regresná analýza", Ekonomický časopis, 60, (2012): 406-419.

Hasan, M. "Transatlantic Open Aviation Area: A Template for a Globalised Civil Aviation Industry?", Aerlines Magazine, 40, (2008): 1-6.

Intervistas. Estimating Air Travel Demand Elasticities, InterVISTAS, Washington, 2007.

Lipková, L'. Medzinárodné hospodárske vztahy, Sprint dva, Bratislava, 2011.

Mayor, K. and Tol, R. S. J. "The Impact of the EU-US Open Skies Agreement on International Travel and Carbon Dioxide Emissions", Journal of Air Transport Management, 14, (2008): 1-7.

Peterson, E. and Graham, T. Open Skies: An Assessment of the US-EU Open Aviation Area Agreement, Purdue University, West Lafayette, 2008.

Robyn, D., Reitzes, J. and Moselle, B. Beyond Open Skies: The Economic Impact of US-EU Open Aviation Area, CEPS, Brussels, 2005.

Zhang, A. and Zhang, Y. "Issues on Liberalization of Air Cargo Services in International Aviation", Journal of Air Transport Management, 8, (2002): 275-287. 


\title{
USPOREDBA PERFORMANSI NEURONSKIH MREŽA PRI PREDVIĐANJU PROPASTI BANAKA I STROJEVA S POTPORNIM VEKTORIMA: SLUČAJ TURSKE
}

\begin{abstract}
SAŽETAK
Iskustvo stečeno u bankarskoj krizi u posljednja dva desetljeća upućuje na potrebu korištenja naprednih modela predviđanja u svrhu prevencije propasti banaka. Ovaj rad uspoređuje sposobnost umjetnih neuronskih mreža i strojeva s potpornim vektorima da predvide propast banaka. lako se umjetne neuronske mreže često koriste za složene probleme u poslovanju, literatura koja spominje strojeve s potpornim vektorima je relativno malobrojna a njihova sposobnost predviđanja propasti banaka nije previše poznata. $U$ ovom radu su ove dvije inteligentne tehnike primijenjene na sklop podataka turskih komercijalnih banaka. Empirijski rezultati pokazuju da iako se predviđanje dvaju modela može smatrati zadovoljavajućim, neuronske mreže pokazuju nešto bolju sposobnost predviđanja od strojeva s potpornim vektorima. Osim toga, različite vrste grešaka u svakom modelu također ukazuju na to da su modeli s neuronskim mrežama bolji prediktori.
\end{abstract}

Ključne riječi: propast banaka, ANN (umjetne neuronske mreže), SVM (strojevi s potpornim vektorima), Turska 